\title{
The Differences in Risk Perception between Millennials and Baby Boomers in Online Transactions
}

\author{
Dipa Mulia \\ Universitas Mercubuana \\ Email:dipa.mulia@mercubuana.ac.id
}

\begin{abstract}
This study aims to distinguish the risks perceived by the millennial generation and the risks perceived by baby boomer generations when transacting online. The number of samples used in this study was one hundred thirty-five respondents. Criteria for respondents are people who have done online transactions in the generation being studied. This study uses a discriminant analysis conducted by a study of three types of risk perceived by respondents, product risk, financial risk, and shipping risk. The result showed there are statistically significant differences in the risks perceived by the millennial generation and the baby boomer generation.
\end{abstract}

Keywords: Perceived risk, Millennial Generation, Baby Boomer Generation, Discriminant Analysis.

\section{INTRODUCTION}

The growth of technology, especially information and communication technology has been felt evenly and globally by the community, no exception in Indonesia. Internet technology based on communication technology is developing rapidly, this is indicated by the increasing number of internet users throughout the world, including in Indonesia. The development of internet technology has triggered the emergence of innovations related to the internet, one of which is trade transactions conducted through communication media or better known as online transactions or e-commerce.

The increase in internet users in Indonesia in recent years has not necessarily been followed by an increase in the growth of transactions conducted online that use the internet as a tool to help proportionately. One statistical data showed the growth of internet users in Indonesia from 2017 to 2018 increased by $43 \%$ but the increase in sales transactions via the internet (e-commerce) increased by only 15\% (Statistia.com, 2019). The relatively slow growth of e-commerce transactions (online) is due to the lack of motivation of internet users to transact online due to different reasons. This general lack of motivation is caused by consumer concerns about this relatively new form of transaction. The feeling of consumer worry is also known as the risk perception of consumers. Things that cause consumers do not make transactions online include uncertainties, long delivery times, difficult to return goods if it turns out to be inappropriate, the cost of shipping (shipping costs), quality is not clear because the goods do not appear physically, online 
services that are less responsive (DI Marketing, 2016). Consumer perceptions of transaction risk (shopping) can be grouped into product risk perception, psychological risk perception, financial risk perception and shipping risk perception (Khan et al., 2015).

One of the efforts to increase e-commerce transactions is to reduce consumers' anxiety in making transactions; for this reason, risk perception from consumers is relevant to study. Discussions related to risks in online transactions have been widely discussed in several countries, one of which is in Southern Africa in an article titled Perceived Risk Experience in online Shopping (Sweigers, 2018).

This study discusses differences in risk perceptions between community groups (consumers) when transacting online by involving certain variables. The variable chosen in the study was perceived risk while the community group (consumers) studied were the millennial generation and the baby boomer generation. The selection of this generation group is because recently the two groups are properly influential on economic and market growth. The baby boomer generation is the generation that has been established with high purchasing power, while the millennial generation is the generation that has begun to enter the market with a sizable amount with good mastery of technology (especially internet technology). This quite striking difference in character is expected to also affect group perceptions of risk, for the sake of this matter, this research is conducted so that it is expected to be objectively examined by different consumer risk perceptions of this generation. In contrast to previous studies, this study does not look for certain variables that affect consumers in online transactions but tests whether the variables that have been studied by previous researchers are judged differently by one group of consumers with other consumer groups.

\section{THEORETICAL REVIEW}

Internet and Online Transactions. Research from (Fitroh, 2018) stated that internet technology had begun since 1958 in the United States and began to launch into Indonesia in the early 1980s. In the late 1980s, several companies engaged in providing internet services (Internet Service Providers/ ISPs) began to emerge. The development of this internet technology went slow because at that time it was still using large-sized computer devices and using telephone communication networks that were still relatively expensive and slow. To be able to access internet technology in the early 1990s, people can use the facilities provided in the form of "internet cafes".

The growth of internet technology is inseparable from the development of hardware technology (hardware) as a supporter. Computer technology changed very rapidly in the early 1990s both in terms of speed and size (dimensions). The same thing also happened in communication technology, especially cell phone devices. Both computers and cell phones are the main supporters of the development of the use of internet technology in Indonesian society. Features developed in the last 10 years that use the internet as a tool for developing very rapidly so that in the last five years the internet has not only been used as a means of communication but has been used as a means of commerce (transacting online). One statistical data shows the growth of internet users in Indonesia from 2017 to 
2018 increased by $43 \%$ and but the increase in sales transactions via the internet (ecommerce) was only $15 \%$ (Statistia.com, 2019).

Forms of online transactions known today are transactions of goods and financial services transactions, some experts define related to online transactions such as electronic commerce (e-Commerce) as the use of the internet and other networks (intranets) to buy, sell, transport, or trade data goods or services; while the Electronic Marketplace (eMarketplace) is an online location where buyers and sellers carry out commercial transactions such as selling goods, services, or information. Each individual can also open a private market that sells products or services online. The electronic market is connected to sellers and buyers via the internet or to partners in their organizations, called intranets (Turban et al., 2017). Another form is known as Fin-Tech (Financial Technology), which is a product or service in the field of finance that is created by using innovation and technology as its tools (Kuo and Teo, 2015).

Theory of Generation. According to (Hansen and Leuty, 2012) generation is defined as a collection of individuals or groups who have a common experience. This similarity in experience is unique so that it can be distinguished from one group to another or from one generation to another. At this time, it is known that several generations actively influence the course of the industry and can influence market mechanisms such as baby boomers, generation $\mathrm{X}$, generation $\mathrm{Y}$ or millennial. Differences in unique experiences between generations are expected to influence attitudes or behaviors in making decisions to transact both online and conventionally (offline). The similarity of experience of each group is not only seen from social and economic aspects such as experiences in the world war, global recession but can also be seen from other aspects such as technological aspects that existed when the group was located, such as the invention of the machine.

The period of one generation with another generation is not always the same; this is largely determined by a very important unique experience that occurred. A war event is an extraordinary event so that different generations will experience war and post-war generations, the same thing will happen if there is a fundamental technological change such as the invention of the machine, there will be a generation before the invention of the machine and after the invention of the machine. The period of differentiating one generation from another is not a rigid one because there is a transition period from one generation to another which is quite different from one place to another. Differences from one generation to another are grouped by experts such as the grouping of generations in the period from the beginning of the 20th century to the end of the 20th century. The identified generations are formulated in Table 1 below. The next generation is known as the 21st-century generation starting with generation $\mathrm{Z}$, a group of people born at the end of the 20th century and the beginning of the 21st century, ranging from 1995 to 2010 and then followed by the alpha generation (Augusto et all., 2018).

Another grouping of generations is seen from their existence together with the existence of technology. Digital technology is a breakthrough that is so extraordinary that people born together with the birth of this technology are given the name of a native digital generation, namely the generation born after 1980 (Cetin and Ozgiden, 2013). The 
native digital generation has used digital technology in daily life since birth, while generations born before this generation already have own technology so to use digital generation this generation must adapt and study digital technology so that this generation is known as the digital immigrant generation (Wu, 2015).

Table 1. Generations of the 20th century

\begin{tabular}{|c|c|c|c|c|}
\hline Reference & & Gener & & \\
\hline (Tapscott, 1998) & $\begin{array}{l}\text { Mature Gen } \\
(<1945)\end{array}$ & $\begin{array}{l}\text { Baby } \\
\text { Boomers } \\
(1946-1964)\end{array}$ & $\begin{array}{l}\text { Gen X } \\
(1965- \\
1982)\end{array}$ & $\begin{array}{l}\text { Gen Y } \\
(1983- \\
1992)\end{array}$ \\
\hline $\begin{array}{l}\text { (Howe and } \\
\text { Strauss, 2000) }\end{array}$ & $\begin{array}{l}\text { Silent } \\
\text { Generation } \\
(1925-1943)\end{array}$ & $\begin{array}{l}\text { Baby } \\
\text { Boomers } \\
(1943-1960)\end{array}$ & $\begin{array}{l}\text { 13th Gen } \\
(1961- \\
1981)\end{array}$ & $\begin{array}{l}\text { Millenial } \\
(1982- \\
2000)\end{array}$ \\
\hline $\begin{array}{l}\text { (Zemke et al., } \\
2000)\end{array}$ & $\begin{array}{l}\text { Veterans } \\
(1922-1943)\end{array}$ & $\begin{array}{l}\text { Baby } \\
\text { Boomers } \\
(1943-1960)\end{array}$ & $\begin{array}{l}\text { Gen-Xers } \\
(1960- \\
1980)\end{array}$ & $\begin{array}{l}\text { Nexters } \\
(1980- \\
2000)\end{array}$ \\
\hline $\begin{array}{l}\text { (Lancaster and } \\
\text { Stillman, 2002) }\end{array}$ & $\begin{array}{l}\text { Traditionalist } \\
(1900-1945)\end{array}$ & $\begin{array}{l}\text { Baby } \\
\text { Boomers } \\
(1946-1964)\end{array}$ & $\begin{array}{l}\text { Gen Xers } \\
(1965- \\
1980)\end{array}$ & $\begin{array}{l}\text { Gen Y } \\
(1981- \\
1999)\end{array}$ \\
\hline $\begin{array}{l}\text { (Martin and } \\
\text { Tulgan, 2002) }\end{array}$ & $\begin{array}{l}\text { Silent } \\
\text { Generation } \\
(1925-1942)\end{array}$ & $\begin{array}{l}\text { Baby } \\
\text { Boomers } \\
(1946-1964)\end{array}$ & $\begin{array}{l}\text { Gen X } \\
(1965- \\
1977)\end{array}$ & $\begin{array}{l}\text { Millenials } \\
(1978- \\
2000)\end{array}$ \\
\hline $\begin{array}{l}\text { (Oblinger and } \\
\text { Oblinger, 2005) }\end{array}$ & $\begin{array}{l}\text { Matures } \\
(<1946)\end{array}$ & $\begin{array}{l}\text { Baby } \\
\text { Boomers } \\
(1947-1964)\end{array}$ & $\begin{array}{l}\text { Gen Xers } \\
(1965- \\
1980)\end{array}$ & $\begin{array}{l}\text { Gen-Y } \\
(1981- \\
1995)\end{array}$ \\
\hline
\end{tabular}

Source: (Yanuar, 2016)

The Baby Boomers Generation. The baby boomer generation is the generation that was born after the Second World War until the 1960s. At this time the baby boomer generation has reached the age of over 50 years, even most of this generation has entered the age of unproductive or retired. This generation is established and even this generation had time to dominate the economy because of its purchasing power and influence in making decisions. Related to aspects of technology, especially digital technology, the baby boomer generation follows various technological developments ranging from simple machine technology to the latest digital technology. As stated earlier, the generation that adapts to digital technology is known as the digital immigrant generation, so the baby boomer generation is an example of the digital immigrant generation.

Regarding work, some researchers claim that the baby boomer generation is a diligent, loyal and obedient generation. Besides this group has a good attitude for him, family and work. The baby boomer generation has a long enough range so that there is a slight difference between the first half (first half period) of the baby boomer and the second half (second half period) of the baby boomer. First, half baby boomers are more concerned with a career and idealism, this is quite different from the second half, although 
it remains loyal to the job, it is more realistic to think of himself and his family. (Zemke et all., 2013).

Millennial Generation. A millennial generation or also known as Generation Y is a group of people who were born in the period 1980 to 1990. This generation grew together with the development of digital technology. Starting when they were in elementary school and into adulthood, this generation was very familiar with computers, internet technology and cell phones with good features. Mastery in the field of digital technology is quite good compared to the previous generation, so this generation belongs to the group of the native digital generation. At this time the millennial generation is starting to affect the economy considering that this generation has begun to increase in number and has good purchasing power. The current millennial generation is a generation that is in a productive period and is expected to influence the economy in the next decade. The millennial generation, in general, is significantly influenced by the baby boomer generation, most of whom are parents of the millennial generation. The behavior of the baby boomer generation is a role model for millennial, such as providing opportunities for women to work and go to college. The big challenges and the high level of expectations of millennial generation shape this generation to have a more confident personality (self-confident) and even tend to narcissism (Lyons and Kuron, 2014). Existence in social media is considered to be one form of success for the millennial generation (Barker, 2012).

The millennial generation is different from the baby boomer generation related to work, millennial generation provides less time to work, and besides that, the loyalty to the employer is relatively low. The millennial generation is very easy to change jobs. The millennial generation is also stated to be the first generation worldwide (going global) because of the support of existing technology (Knight, 2014). Not surprisingly, by the age of 30, millennial have moved more workplaces than baby boomers (Lyon et all., 2015). The difference in characteristics between millennial and baby boomers is expected to influence the behavior or attitudes of the two generations in dealing with risks when transacting online.

The baby boomer generation and millennial generation in Indonesia grow in different conditions in several ways, such as social, economic and cultural aspects. The baby boomer generation is currently the most unproductive generation due to the age that is already above 50 years while the generation of millennial is the productive generation and is still produced in the next 20 years. Economic, social and cultural conditions also influence differences in the level of generational education as well as the influence of technological developments in each generation, as summarized in Table 2. Attention to millennial is very important because it is properly influential in social life and also in the economy in the period 10 to 20 years into the future, as well as online transactions that are currently developing are influenced by the development of this millennial generation. The projected distribution of Indonesia's population in 2020 is expected to be dominated by millennial generation at $34 \%$ of the total population, while the baby boomer generation is only $13 \%$ of the total population (BPS, 2013). 
Table 2. Baby Boomers and Millennial in Indonesia

\begin{tabular}{|c|c|c|}
\hline & Baby Boomer (1946-1965) & Millennial (1982-2000) \\
\hline Current age & 54-73 (Less Productive) & 19-36 (Productive) \\
\hline Community situation & Agrarian Society & Industrial Society \\
\hline National Economic & Surviving & Growing \\
\hline Technology & Slow Change & Fast Change \\
\hline \multicolumn{3}{|l|}{ Development } \\
\hline Level of Education & $\begin{array}{l}\text { Average Senior High School } \\
\text { or Diploma } 3 \text { Degree }\end{array}$ & Bachelor Degree \\
\hline Labor Composition & Male domination & Male and Female \\
\hline
\end{tabular}

Source: (Hasanudin and Lilik, 2016)

Risk Perception. Risk perception has been studied since 1960 related to consumer behavior that has no interest in buying, this is very influential in business so the cause needs to be studied (Zhang et all., 2015). Risk perception is significantly important in consumer behavior because basically, consumers would not like to make mistakes in having a decision (Farzianpour et all., 2014). The occurrence of conditions that are not desired by consumers is the core of risk perception; this is closely related to consumer behavior.

Associated with online transactions, risk perception is described as a reluctance (there is no motivation) consumers to make online transactions due to concerns and uncertainties that are more likely to transact conventionally or offline (Persad and Padayachee, 2015). The risk experienced by consumers due to the possibility that the product selected may fail to meet needs is referred to as product risk or product risk (Abrar et all., 2017). Another risk faced by consumers when transacting online is the possibility of not having the appropriate product after completing online transactions and making payments to online stores, this is known as the risk of shipping or delivery risk (Abrar et all., 2017). Delivery risks also include the possibility of damage to goods in transit due to negligence of the shipping company (Claudia, 2012). In addition to product risk and consumer shipments that transact online, they are also faced with the possibility of financial losses due to hidden costs or other unexpected losses; this is known as financial risk (Zhang et all., 2012). According to (Kaur and Quareshi, 2015), things that result in consumers not wanting to do online transactions include uncertainty, long delivery times, difficult to return goods if it turns out to be inappropriate, there are shipping costs, the quality is unclear because the goods do not appear physically, online services are less responsive.

(Hong and Cha, 2013) conducted a study of the effect of risk perception on customer repurchase intention on online shopping sites. The risk perception variables used are product performance risk perception, psychological risk perception, social risk perception, financial risk perception, online payment risk perception, and perception delivery risk. The study concluded that product performance risk perception, psychological risk perception, 
financial risk perception, and online payment risk perception have a negative and significant effect on customer repurchase interest on online shopping sites. Research that concluded there is a negative influence of the test variable showed that the variable is worth mentioning as a risk. Consumer perceptions of transaction risk (shopping) can be simplified into product risk perception, psychological risk perception, financial risk perception and shipping risk perception (Khan et all., 2015).

Previous research showed that indicators that are considered important by consumers that can reduce risk perception are product quality, clear information about the product and company background, in terms of online transactions referred to by the company is an e-commerce platform (Beneke, 2013). Another thing that can reduce consumers' risk perception in online transactions is a return policy, meaning consumers can exchange products if they are not suitable or can receive their money back if they cannot find an appropriate product (Powell, 2015). The ease of use of technology helps reduce risk perceptions of online transactions; technological ease is defined as the knowledge and ability of consumers to use technology easily (Zaidi et all., 2014).

\section{METHODOLOGY}

The purpose of this study is to evaluate whether there are differences in risk perception between millennial and baby boomers when transacting online. This research is a quantitative study using discriminant analysis of selected variables, which are variables that are considered to influence respondents when transacting online. The variables chosen in this study are Perceived Risk of Product, Perceived Risk of Financial and Perceived Risk of Delivery. The risk perception variable of the product is measured using five (5) indicators; succession, design, size, color, function (performance) aspects, which are then given a PR1 to PR5 notation. Variable risk perceptions of financial aspects are measured using four (4) indicators, which are successively the product's fair price, product prices elsewhere, payment processing, and money-back claims, then given a notation FI1 through FI4. Perception of shipping risk is measured by using five (5) indicators in a row are wrong address, the process cannot be traced, wrong product, the wrong quantity of goods, the driver is late, then given a notation of DE1 to DE5. The selection of this variable refers to previous research that was presented at the 2018 National Seminar on Social and Applied Science Conference (SASC) (Novita and Dipa, 2018).

Measurement of indicators is done by using a questionnaire. The questionnaire used in this study is a statement that must be assessed by the respondent whether the respondent agrees or not with the statement. The assessment is carried out using a Likert scale with a scale of numbers 1 to 5 , where a value of 1 indicates that the respondents strongly disagree with the statements submitted in the questionnaire and number 5 shows that the respondents strongly agree with the statements in the questionnaire while numbers 2 to 4 are gradations between the very agree and strongly agree. Statements related to risk perception in the questionnaire are delivered in the form of negative circumstances (not favorable to the respondent) using the word "no" or words that mean "negative" or "not expected to occur" by consumers. Examples of statements in the questionnaire are as 
follows: (1) The product color is "not the same" as the product color displayed on the online shopping site $X$. (2) Online shopping site $X$ sends products that are "wrong/incompatible" with orders. (3) The refund process is "difficult to do" if a complaint/complaint occurs or the product ordered is not available.

The form of this statement implies that the greater the Likert scale number submitted by the respondent means the greater the respondents' risk perception of the indicator and conversely the smaller the Likert scale number delivered by the respondent shows the risk perception of the respondent towards the statement (indicator) the lower. For example, the statement (a) is related to the color of the product which is not the same as the one on the site. The evaluation of respondents in high Likert scale figures showed that color is a high risk, and vice versa. The same thing happens in the statement (c) which uses the word "difficult" which means it is not expected to occur or is perceived as being at high risk.

Criteria for respondents in this study are people who belong to the baby boomer generation group or millennial generation who have done online transactions that are limited to goods transactions and do not include services transactions in the financial sector (Fin-tech). Such online transactions are not limited to the purchase of certain products or certain e-commerce platforms. This study assumes that the e-commerce platform and the product purchased do not affect the respondent's attitude to risk perception.

The criteria used to measure the validity of the data and the reliability of the model are carried out using the loading factor (LF) criteria> 0.4 for validity and Construct Reliability (CR) $>0.7$ for reliability. Discriminant analysis is performed on the three risk perception variables above. The analysis showed whether there is a significant difference in risk perception between the millennial generation and baby boomer generation towards these three risks (variable). The null hypothesis of this study is

Ho: There is no significant difference in risk perception between the millennial generation and baby boomer generation in online transactions.

\section{THE RESULTS OF STATISTICAL TESTS AND DISCUSSION}

The number of respondents who met the criteria for this study was collected as many as 135 respondents and as many as 69 respondents as the baby boomer generation group and 66 people as the millennial generation. Variables used in the test the risk perception of respondents are product risk perception. Financial risk perception and delivery risk perception. Each variable of risk perception is measured by related indicators which are then tested for their association with the CFA (Confirmatory Factor Analysis) method. The result of the Confirmatory Factor Analysis (CFA) on indicators describing risk perception variables on products (PR1 through PR5), indicators of financial risk perception variables (FI1 through FI4) and indicators of shipping risk perception (DE1 through DE5) indicate that all indicators has a relationship with variables with a weight (loading factor) greater than 0.4 , thus all indicators are eligible to be used as explanatory variables. Construct Reliability (CR) for each variable> 0.7 so that all variables are 
declared reliable (Sharma, 2016). The magnitude of the loading factor and construct reliability (CR) for each indicator are presented in Table 3.

Loading factor showed how strong the indicator can explain the variable, high loading factor indicates that the indicator contributes high in explaining the variable. Referring to Table 3, the perceived risk of the product variable has the highest loading factor is the PR5 indicator of 0.61. PR5 is an indicator related to the function or product performance aspect, meaning that the product risk perception is explained quite high by the product function/ performance indicator or in other words the product function/ performance explains the product risk well. The PR5 performance indicator is 2.7 based on the Likert scale 1 to 5 . As stated in the research methodology, this study uses a questionnaire with a negative statement and the Likert scale used is 1 for assessment strongly disagrees with the statement and 5 strongly agrees with the statement, thus the number High performance showed that the indicator is considered very risky. Respondents' expectations of the performance indicators are all low-risk indicators. PR5 is an indicator with the highest loading factor and the lowest risk performance number means that the performance of this indicator is better than other indicators. Another case with the perception of financial risk is explained by indicators FI1 to FI4. The highest loading factor is owned by FI4, namely cashback claims, which means cashback claims are the main contributors in explaining perceptions of financial risk. The performance of the FI4 indicator is 2.94, this figure is the second-highest number in the perception of financial risk, it showed the FI4 indicator needs attention now to be improved because it is considered riskier than other indicators remembering the highest contribution in explaining the perception of financial risk.

Table 3. Indicator's Loading factor

\begin{tabular}{ccccc}
\hline Variables & Indicators & Loading & CR & Performance \\
\hline product risk & PR 1 & 0.49 & 0.85 & 2.75 \\
perception & PR 2 & 0.58 & & 2.96 \\
& PR 3 & 058 & & 2.74 \\
& PR 4 & 0.52 & & 2.79 \\
& PR 5 & 0.61 & & 2.70 \\
Financial risk & F1 & 0.56 & 0.80 & 3.00 \\
perception & F2 & 0.60 & & 2.84 \\
& F3 & 0.67 & & 2.77 \\
Delivery risk & F4 & 0.68 & & 2.94 \\
perception & DE 1 & 0.50 & 0.87 & 2.36 \\
& DE2 & 0.56 & & 2.62 \\
& DE3 & 0.68 & & 2.60 \\
& DE 4 & 0.67 & & 2.47 \\
& DE5 & 0.54 & & 2.72 \\
\hline
\end{tabular}

Source: (Output Lisrel , 2019) 
Each respondent gives an assessment indicator of the statement; each indicator acquires a number between 1 to 5 (according to the Likert scale). The indicator number is used to determine the performance rate of each variable (risk perception) by considering the loading factor (weight) of each indicator in explaining the variable known as the weighted average method. The performance of each variable for each respondent is averaged so that the average performance of each variable is formed. There is a difference in the average performance of the variables between the millennial generation and baby boomer generation, as illustrated in Table 4.

The performance of each variable was measured for each group of data, both for the baby boomer generation group (generation 1) and the millennial generation group (generation 3). Generation 1 has a lower average product risk perception variable performance than Generation 3, this showed that product risk is relatively less important by Generation 1 compared to Generation 3. The analysis of the average number should also consider the standard deviation rate so that a discussion of the performance is carried out in a range around the average number.

Referring to table 4 using rounding, the range of performance of the product perception variable for generation 1 is $2.6+/-0.7$ (or range of values 1.9 to 3.3) while for generation 3 is $3+/-0.4$ (or the range of values 2.7 to 3.4 ). The range of generation 1 and generation 3 values for overlapping product risk perception variables showed that although the average generation 1 has the lower performance for the variables tested in reality some generation 1 respondents assess the performance of the variable tested is greater from the assessment of respondents from generation 3. The same method in the analysis of variable performance is carried out for other test variables, thus obtained the performance of the financial risk perception variable for generation 1 in the range (2 to 3.4) while for generation 3 is (2.3 to 3.7). The performance variables of shipping risk perception are (1.7 to 3 ) for generation 1 and (2.2 to 3.4) for generation 2 .

At a glance, the performance of the variables of the two generations has shown differences in risk perception between the two generations tested, but to find out how significant these differences are and how strong the differences are then the discriminant analysis is used to further evaluate.

Table 4. Variable Performance

\begin{tabular}{llccc}
\hline \multicolumn{1}{c}{ Generation } & Type of Risk & Mean & Std. Deviation & \# of samples \\
\hline 1 (Babyboomer) & Product & 2.61 & 0.68 & 54 \\
& Finance & 2.66 & 0.66 & 54 \\
& Delivery & 2.33 & 0.64 & 54 \\
3 (Millenials) & & & & 51 \\
& Product & 2.99 & 0.39 & 51 \\
& Finance & 3.12 & 0.64 & 51 \\
\hline
\end{tabular}

Source: (Output SPSS, 2019) 
Discriminant analysis was carried out using 54 respondents from the baby boomer generation and 51 respondents from the millennial group. The baby boomer group was given notation 1 (Generation 1) while the millennial generation was given notation 3 (Generation 3). The result of the discriminant analysis are presented in several standard measures such as the level of significance, the coefficient of the variable (coefficient), and the determination of the discriminant function (discriminant score) with the centroid for each group tested. Tests have also been carried out on the accuracy of the discriminant function in predicting the group of respondents by taking into account the perceived value of risk in this study. As a test of the discriminant function obtained, 30 respondents consisted of 15 respondents from the baby boomer group and 15 respondents from the millennial group who provided information related to the respondents' perceptions of the selected variables (Perceived risk of Product, Perceived risk of Financial and Perceive risk of Delivery). including:

By the objectives of the study, the discriminant analysis showed several results

Correlation coefficient. The correlation coefficient is an indication of how strong the relationship between the variables measured. In this study, the correlation between variables ranged from 0.29 to 0.47 , as illustrated in Table 5, which means that all variables correlated positively, even though the correlation coefficient is still relatively small so the relationship between variables is declared weak because of the correlation coefficient between variables $<0.6$. This condition showed that there is no multicollinearity between variables (each variable is not closely related). Multicollinearity occurs if the threshold of the correlation coefficient number is exceeded. The threshold correlation coefficient is around 0.8, or the VIF (Variance Inflation Factor) threshold that is in the range of 10 is exceeded. Nevertheless, some researchers set threshold figures for correlation coefficients of 0.6 and VIF 5 (Tay, 2017).

Table 5. Correlations between Variables

\begin{tabular}{lccc}
\hline & Product & Finance & Delivery \\
\hline Product & 1 & 0.295 & 0.436 \\
Finance & 0.295 & 1 & 0.473 \\
Delivery & 0.436 & 0.473 & 1 \\
\hline
\end{tabular}

Source: (Output SPSS, 2019)

Hypothesis Testing. Referring to Table 6, the result of this test indicated that the financial aspect risk perception variable and the shipping aspect risk perception have a significant number $(\mathrm{sig})=0$ while the product aspect risk perception variable has a significance of 0.001 . All variables have a significance $(\mathrm{sig})<0.05$, which means that the three variables make a significant difference in the group or in other words the variable is judged differently by the group tested significantly. The result of discriminant analysis give 
significance $(\mathrm{sig})=0,000$ or $\mathrm{sig}<0.05$ which means that the tested variables show differences between groups of generations, even though the number of Wilk's Lambda is still large at 0.825 . The differences between groups tested will be large if the number of Wilks' Lamda is close to 0 . This study explained that there are significant differences between groups but not too large. Eigenvalue showed the proportion of variance (difference) that can be explained, that is 0.212, the greater the Eigenvalue, the greater the proportion of the difference that can be explained (maximum number of Eigenvalues $=1$ ). Canonical correlation $(\mathrm{CC})$ with a value of 0.418 so that the $\mathrm{CC}$ square $=0.175$. This figure is in line with the Eigenvalue that the three selected variables can already show significant differences in perception; however, the three variables used can only explain the difference of the remaining $17.5 \%$ explained by other things.

Discussion of the result of the discriminant analysis above is used as a tool to test the null hypothesis that has been set, it should be noted that the most important thing in the test the null hypothesis is significance. The hypothesis test result showed sig. $=0<0.05$ shows that the null hypothesis is rejected, meaning that there is a statistically significant difference between millennial risk perceptions and baby boomer risk perceptions when transacting online even though the difference is not strong enough. The difference that is not strong enough is probably because in this study there is no difference in the types of products purchased online. The variety of products purchased by consumers varies from clothing, furniture, spare parts, cell phones, electronic equipment, food, all of which are assumed to not affect risk perception. For example respondent A would assess the same risk perception for shipping error indicators when buying electronic products and buying food. This might not be right. In addition, this study also assumed that all e-commerce platforms do not affect respondents' ratings of transactions meaning that when respondent A purchases electronic goods in e-commerce platform $X$ and purchases the same items in e-commerce platform $\mathrm{Y}$, it is assumed that the perception of risk is the same without regard to credibility from each e-commerce platform.

Nevertheless, the result of this test is quite in line with other previous studies related to the behavior of these two generations. As stated above, in terms of the work of the millennial generation, they prefer to move, while the baby boomer generation is more loyal. This reflects the difference between the two generations in taking risks in choosing work.

Table 6. Significance and Strength

(a) Test of Equality of Group Means

\begin{tabular}{lccc}
\hline & Wilks' Lambda & F & Sig. \\
\hline Product & 0.894 & 12.226 & 0.001 \\
Finance & 0.888 & 13.014 & 0.000 \\
Delivery & 0.880 & 14.071 & 0.000 \\
\hline \multicolumn{2}{c}{ Source: (Output SPSS }
\end{tabular}


(b) Wilks' Lambda

\begin{tabular}{ccccc}
\hline Test of Function & Wilks' Lambda & Chi - Square & df & Sig. \\
\hline 1 & 0.825 & 19.489 & 3 & 0.000 \\
\hline
\end{tabular}

Source: (Output SPSS, 2019)

(c) Eigenvalues

\begin{tabular}{cccc}
\hline Function & Eigen value & \% of Variance & Cannonical Correlation \\
\hline 1 & 0.212 & 100 & 0.418 \\
\hline
\end{tabular}

Source: (Output SPSS, 2019)

Referring to Table 4. Variable Performance, it appears that the average performance of the millennial generation (generation 3) is greater than the average performance of the baby boomer generation (generation 1) variable for all variables tested. This showed that in general millennial generation risk perception of online transactions is higher than the baby boomer generation risk perception for the three variables tested. The result of this test is in line with some of the theories above which stated that the millennial generation is a generation that has high expectations (demanding) so it is less able to tolerate errors in the online transaction process. The familiarity of the millennial generation with internet technology also contributes to shaping the attitude of the millennial generation to under-accept errors of online transaction processing. Somewhat different from the baby boomer generation who are digital immigrants, being more tolerant of mistakes by considering the transition in the use of technology. Also, in terms of the financial risk perception of the baby boomer generation is lower than the millennial generation, this can be explained because the products that are commonly purchased are still below the purchasing power of the relatively well-established baby boomer generation. The criteria chosen as respondents are people who have transacted online, this research indicated that the baby boomers who transact online are better prepared to face risks than millennial groups.

Discriminant Function (D score). The discriminant function is built by the coefficient of the risk perception variable under study so that the discriminant function can help predict whether a respondent (consumer) is classified as a millennial or baby boomer based on his assessment of the risk perception studied. The accuracy of the discriminant function in predicting the compatibility of the variable with the group being tested is expressed in terms of Hit Ratio.

The statistical test result in Table 7, showed that the risk perception of the product has a coefficient of 0.796 while the risk percentage for financial is 0.700 and the perception of shipping risk is 0.633 . These result indicated that the risk perception of the product is the main differentiator between the millennial generation and the baby boomer generation. 
The discriminant function (D) can be written down, $\mathrm{D}=0.796$ Product +0.700 Financial +0.633 Delivery $-5,854$

Centroid group, which is the center of each group in discriminant score (D), for Baby Boomers $=-0.443$ while for Millennial $=0.469$ with a cut-off $(Z)$ close to 0 , so for respondents who get discriminant scores $\mathrm{D}<0$ will be classified as in the Baby Boomer group while $\mathrm{D}>0$ belongs to the Millennial group.

Table 7. Discriminant \& Centroid Function Coefficient

(a) Canonical Discriminant Function Unstandardized Coefficient

\begin{tabular}{lrr}
\hline & Variabel & Coefficient \\
\hline Product & 0.796 \\
Finance & 0.700 \\
Delivery & 0.633 \\
Constant & -5.854 \\
\hline
\end{tabular}

Source: (SPSS Output, 2019)

(b) Function at Group Centroid

\begin{tabular}{lr}
\hline \multicolumn{1}{c}{ Generation } & Function \\
\hline 1 (Babyboomers) & -0.443 \\
3 (Millenials) & 0.469 \\
\hline
\end{tabular}

Source: (SPSS Output, 2019)

Hit Ratio. The accuracy of the discriminant function (E) (D score) to predict whether respondents can enter the baby boomers or millennial groups based on risk perception, namely Perceived Risk of Product, Perceived Risk of Finance and Perceived Risk of Delivery. The accuracy test of the discriminant function prediction (D score) is illustrated in the hit ratio table. Hit ratio table obtained from 30 respondents (who are part of the research sample) has answered a questionnaire consisting of 14 statements using a Likert scale from 1 to 5. Risk perception figures (Product, Financial, Delivery) are obtained from indicator indicators that explain them by considering loading factor (weight) obtained from the Confirmatory Factor Analysis (CFA) so that it is possible to get a number that is not round (fraction or decimal). Calculation of $\mathrm{D}$ score (D) is done by applying the following formula:

$\mathrm{D}=0.796$ Product +0.700 Financial +0.633 Delivery $-5,854$

Referring to the predetermined criteria, for group 1 it should have a D score $<0$ while group 3 has a D score $>0$. The table shows that there are three unsuspecting respondents from group 1 and three respondents from group 3. Referring to Table 8, there are 30 respondents were used as test equipment, only 24 respondents were predicted correctly 
and there were 6 (six) predictive mismatches on the D score, namely test sample no. 7, 13, $15,19,21,23$, thus it was said that the hit ratio was $80 \%$.

Hit ratio can also be interpreted as a tool for estimating consumer behavior (respondents) to the variables studied. This study shows that the differentiating factors of baby boomer generation with millennial generation are product risk perception, financial risk perception, and shipping risk perception, so if there are found respondents (consumers) who are classified as millennial generation, then respondents can be predicted at risk perception by $80 \%$ which is different from the baby boomer generation.

Table 8. Hit Ratio (Confirmatory Test)

\begin{tabular}{|c|c|c|c|c|c|c|c|c|c|c|c|}
\hline No & Group & Product & Financial & Delivery & DScore & No & Group & Product & Financial & Delivery & DScore \\
\hline 1 & 1 & 1,8 & 3,5 & 2,8 & $(0,199)$ & 16 & 3 & 3 & 3,5 & 3,6 & 1,263 \\
\hline 2 & 1 & 2,4 & 2,75 & 2,2 & $(0,626)$ & 17 & 3 & 3 & 3 & 4,4 & 1,419 \\
\hline 3 & 1 & 2,6 & 2,75 & 2,8 & $(0,087)$ & 18 & 3 & 3 & 3 & 3 & 0,533 \\
\hline 4 & 1 & 2 & 1,75 & 1 & $(2,404)$ & 19 & 3 & 2,6 & 2,5 & 2,2 & $(0,642)$ \\
\hline 5 & 1 & 2,4 & 2,5 & 2,4 & $(0,674)$ & 20 & 3 & 3 & 3 & 3 & 0,533 \\
\hline 6 & 1 & 2,4 & 1,75 & 1,2 & $(1,959)$ & 21 & 3 & 3 & 2,5 & 2,2 & $(0,323)$ \\
\hline 7 & 1 & 3 & 3,5 & 3 & 0,883 & 22 & 3 & 3,4 & 3,75 & 3,4 & 1,630 \\
\hline 8 & 1 & 2 & 2 & 2 & $(1,596)$ & 23 & 3 & 2,6 & 2,75 & 2,4 & $(0,340)$ \\
\hline 9 & 1 & 2,8 & 2 & 1,4 & $(1,339)$ & 24 & 3 & 3 & 3,5 & 3 & 0,883 \\
\hline 10 & 1 & 2,8 & 2 & 2 & $(0,959)$ & 25 & 3 & 3,2 & 3,75 & 3,2 & 1,344 \\
\hline 11 & 1 & 3 & 2,75 & 2 & $(0,275)$ & 26 & 3 & 3,2 & 3,75 & 3,1 & 1,281 \\
\hline 12 & 1 & 2,4 & 2,75 & 1,8 & $(0,879)$ & 27 & 3 & 3,2 & 3,75 & 3,1 & 1,281 \\
\hline 13 & 1 & 3 & 3,25 & 3 & 0,708 & 28 & 3 & 3,3 & 3,5 & 2,8 & 0,995 \\
\hline 14 & 1 & 2,2 & 1,75 & 2,2 & $(1,485)$ & 29 & 3 & 2,8 & 3 & 2,8 & 0,247 \\
\hline 15 & 1 & 3 & 3 & 3 & 0,533 & 30 & 3 & 3 & 3,5 & 3 & 0,883 \\
\hline
\end{tabular}

Source: (Output, 2019)

In general, this research has succeeded in showing that there are significant differences between the behavior of the baby boomer and millennial groups. The result of this study is the difference between this study and previous studies in which previous research studies show that perceived risk is negatively correlated to online buying interest without differentiating generation differences from buyers (consumers). (Hong and Cha, 2013; Kesharwani and Bisht, 2012).

\section{CONCLUSION}

The study concluded that there were significant differences between the millennial generation and baby boomer generation in assessing risk when transacting online, even though the difference was not very strong. The risk perception chosen in this study, 
namely Perceived Risk of Product, Perceived Risk Financial and Perceived Risk Delivery can show this difference by $17.5 \%$ while the rest needs to be explained by other risk perceptions.

Suggestion. The biggest coefficient on the discriminant function is the risk perception of the product. Indicators used to explain risk perceptions of products include durability, design, size, color, and function, hence it can be stated that millennial generation perceptions are different from baby boomer generations in assessing these indicators. This result is used by producers or e-commerce platforms to provide products of different characteristics so that the needs of the millennial generation and baby boomer generation are met. Nevertheless, the aspects of financial risk and aspects of shipping risk also help distinguish the risk perceptions of the two groups, so indicators explaining the perception of financial risk and shipping need to be considered as well. This research is not perfect because the variables used are only able to explain the differences between the two generations accurately by $17.5 \%$ so that further research can be done by adding other variables or by setting other criteria.

This research assumed that the product purchased and the e-commerce platform does not affect risk perception, so this research mixes all respondents with the purchase of a very diverse product range (cosmetics, clothing, spare parts, furniture, electronic equipment, cellular phones, etc.) purchased from the platform. E-commerce is also significantly diverse. This needs to be a concern for subsequent research to be able to consider research by dividing products into certain classes that are more homogeneous and dividing e-commerce platforms with a certain level of performance as well.

\section{REFERENCES}

Abrar, Kashif; Muhammad Naveed and Muhammad I Ramay. (2017) "Impact of Perceived Risk on Online Impulse Buying Tendency: An Empirical Study in the Consumer Market of Pakistan". Journal of Accounting \& Marketing. Volume 6.

Ali Zaidi, S. D., Gondal, B. J., and Yasmin, A. (2014) "Antecedents of Online Shopping Intention: A Study held in Pakistan”. Journal of Sociological Research, 5(1), 231247

Augusto, T., Gomes, C., Fernanda, C., Bezerra, D. M., Oste, G., and Cremonezi, G. (2018). "Study on The Alpha Generation And The Reflections of Its Behavior in the Organizational Environment", Quest Journals Journal of Research in Humanities and Social Science, 6(1), 9 -19

Barker, V. (2012) "A generational comparison of social networking site use: The influence of age and social identity", International Journal of Aging and Human Development, 74(2), 163-187.

Beneke, Justin. (2013) "The influence of perceived product quality, relative price, and risk on customer value and willingness to buy: a study of private-label merchandise." Journal of Product \& Brand Management, 218-228

Biro Pusat Statistik, (2013) Proyeksi Penduduk Indonesia 2010 - 2035, Jakarta: BPS 
Cetin M, and Ozgiden H (2013). "Dijital Kultur Surecinde Dijital Yerliler Ve Dijital Gocmenlerin Twitter Kullanim Davranislari Uzerine Bir Arastirma”. Gumushane Universitesi Iletisim Fakultesi Elektronik Dergisi, 172- 189.

Claudia, I., (2012) "Perceived Risk when Buying online", Economics Series, 22(2), 63-73.

DI Marketing. (2016). E-commerce Usage In Indonesia 2016. http://www.dionlinesurvey.com/en/2016/09/23/e-commerce-usage-in-indonesia-2016/ (Diakses Tanggal 11 September 2017).

Farzianpour, F., Pishdar, M., Shakib, M.D., Toloun, M.R.S. (2014) "Consumers' perceived risk and its effect on adoption of online banking services", American Journal of Applied Sciences, 11(1), 47-56.

Fitroh Maimunah, (2018) Sejarah Perkembangan Internet di Indonesia yang Banyak Orang Tidak Tahu, (diakses dari bixbux.com pada Tanggal 2 / 2/ 2019).

Hansen J.C. and M.E. Leuty M. E (2012) "Work Values Across Generations". Journal of Career Assessment. 20(01), 34 - 52. ISSN 1069-0727.

Hasanudin Ali and Lilik. P. (2016) Indonesia 2020: The Urban Middle-Class Millenials, Jakarta: Alvara.

Hong, I.B. and Cha, H.S. (2013) "The mediating role of consumer trust in an online merchant in predicting purchase intention". International Journal of Information Management 33. 927-939.

Kaur, G. and Quareshi, T. K. (2015) "Factors obstructing intentions to trust and purchase products online". Asia Pacific Journal of Marketing and Logistics, 27(5): 758-783.

Kesharwani, A. and Bisht, S.S. (2012) "The Impact of Trust and Perceived Risk on Internet Banking Adoption in India: An Extension of Technology AcceptanceModel". International Journal of Bank Marketing, 30(4):303-322.

Khan, S.A., Liang, Y. dan Shahzad, S. (2015) "An Empirical Study of Perceived Factors Affecting Customer Satisfaction to Re-Purchase Intention in Online Stores in China”. Journal of Service Science and Management, 8. 291-305.

Knight, R. (2014)."Managing people from 5 generations". Harvard Business Review [online]. Link - https://hbr.org/2014/09/managing-people-from-5-generations. ISSN $\underline{0017-8012}$

Kuo Chuen, D.L., and E.G. Teo, (2015) "Emergence of FinTech and the LASIC principles", Journal of Financial Perspectives. 3(3), 2015, pp. 24-36.

Lyons, S., and Kuron, L. (2014) "Generational differences in the workplace: A review of the evidence and directions for future research". Journal of Organizational Behavior, 35(S1), S139-S157.

Lyons, S.T., Schweitzer, L., and Ng, E.S. (2015) "How have careers changed? An investigation of changing career patterns across four generations". Journal of Managerial Psychology, 30(1), 8-21.

Novita R. P., dan Dipa M, (2018) "Faktor Faktor yang Mempengaruhi Minat Beli Pelanggan Pada Situs Belanja Online X”, Seminar Nasional - Social and Applied Science Conference (Proceeding), Universitas Mercu Buana. 
Persad, K. and Padayachee, K. (2015) "The factors that influence customer e-services adoption". South African Consumer Journal, 56: 80-22

Powell, C. Michael and Christopher A.C. (2015) "Perceive Risk Agents in E-commerce Environments", Journal of Technology Research, Vol 6, 1 - 7.

Sharma, S. (2016). Applied multivariate techniques Subhash sharma.pdf, diakses dari https://pdfentity.co/downloads/applied_multivariate_techniques_subhash_sharma.pd f.

Statista, (2019) E-Commerce Indonesia, (diakses dari www. Statistia.com pada 8/1/2019)

Sweigers, Liezel. (2018) Perceived Risk Barrier to online shopping: Experiences of Technologically Enabled Generation Y Consumer, Stellenbosch University.

Tay, Richard. (2017) "Correlation, Variance Inflation, and Multicollinearity in Regression Model", Journal of Eastern Asia Transportation Society.

Turban, E., Whiteside, J., King D., and Outland, J. (2017) Introduction to Electronic Commerce and Social Commerce. Fourth Edition. Springer International Publishing. Switzerland.

Wu, CL. (2015) Digital Natives and Digital Immigrants in Anti-Nuclear Campaign: From Media and Technology Usage and Citizen Participation Perspectives. Taiwan: National Sun Yat-Sen University.

Yanuar S. P., (2016) "Teori Perbedaan Generasi”, Among Makarti, 9(18), 123-134.

Zemke, Susan, C. Raines, B Filipczak. (2013) Generations at Work: Managing the Clash of Boomers, Gen Xers, and Gen Yers in the workplace, New York: AMACOM.

Zhang, L., Tan, W., Xu, Y. and Tan, G. (2012) "Dimensions of consumers' perceived risk and their influences on online consumers' purchasing behavior". Communications in Information Science and Management Engineering, 2(7), 8-14.

Zhang, Y., Wan, G., Huang, L., and Yao, Q. (2015) "Study on the impact of perceived network externalities on consumers' new product purchase intention". Journal of Service Science and Management, 8(1), 99-106. 